\title{
State Intervention for Growth Promotion in Market Economies
}

\section{Kesner-Škreb, Marina}

Source / Izvornik: Occasional Paper Series, 1997, 1, 1 - 33

Journal article, Published version

Rad u časopisu, Objavljena verzija rada (izdavačev PDF)

https://doi.org/10.3326/ops.1

Permanent link / Trajna poveznica: https:/urn.nsk.hr/urn:nbn:hr:242:776601

Rights / Prava: Attribution-NonCommercial-NoDerivatives 4.0 International/ImenovanjeNekomercijalno-Bez prerada 4.0 međunarodna

Download date / Datum preuzimanja: 2023-04-26

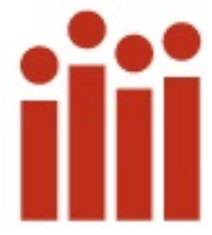

Institute of Public Finance Repository

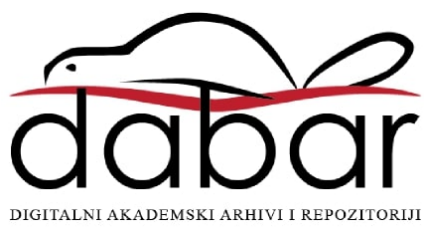


ISSN 1331-1743

doi: $10.3326 /$ ops.1

The Institute of Public Finance is a public organization engaged in research in public finance. The Institute publishes Occasional Papers. These papers are English language translations of articles or summaries of research projects published in the Institute's scientific journal "Financijska praksa". The views expressed there are those of the authors and not those of the Institute.

The members of the Editorial Board are: Ivo Biæaniæ (University of Zagreb), Marina Kesner Škreb (Institute of Public Finance) and Katarina Ott (Institute of Public Finance). The occasional papers are distributed free of charge. For additional information please contact:

Ms Marina Kesner Škreb

Senior Research Project Manager

Institute of Public Finance

Katanèiæeva 5

10000 Zagreb

CROATIA

tel: +38514591227

fax: +38514819365

e-mail: SKREB@IJF.HR

Please visit the Institute's web site: http://www. ijf.hr 


\title{
STATE INTERVENTION FOR GROWTH PROMOTION IN MARKET ECONOMIES
}

\author{
Marina Kesner Škreb \\ Occasional Paper No. 1 \\ January 1997
}

Institute of Public Finance

Katanèiæeva 5, 10000 Zagreb CROATIA

tel: +3851433006

fax: +3851277089

http://www.ijf.hr

C Institute of Public Finance 1997 


\title{
STATE INTERVENTION FOR GROWTH PROMOTION IN MARKET ECONOMIES
}

\author{
Marina Kesner Škreb
}

This Occasional Paper presents a summary of research conducted in the project entitled "State Intervention For Growth Promotion in Market Economies" undertaken by the Institute of Public Finance and financed by the Croatian Chamber of Commerce. The complete collection of papers written for the project was published in the Institute's journal "Financijska praksa", Volume 19, Number 5 (February 1996). The project's lead researcher was Ms Marina Kesner Škreb. The papers were written by Ms. Dubravka Jurlina Alibegoviæ and Ms. eljka Kordej De Villa (Economics Institute, Zagreb), Ms. Danijela Kuliš, Ms. Marina Kesner Škreb and Dr. Katarina Ott (Institute of Public Finance), Dr. Mia Mikiæ (University of Auckland, Auckland). The project's consultant was Dr. Ivo Biæaniæ (Faculty of Economics, Zagreb and Central European University, Budapest) who also made the English translation. The purpose of the project was to analyze the experiences of industrial policies in selected market economies. The results of the research would then be used as background papers for another project aimed at the formulation of Croatian industrial policy. 


\section{STATE INTERVENTION FOR GROWTH PROMOTION IN MARKET ECONOMIES \\ Marina Kesner Škreb}

\section{ABSTRACT}

The purpose of the project was to analyze how state intervention, or, more precisely industrial policy, influences market economies. The countries selected for case studies were: Austria, Chile, the European Union, Germany, Japan, New Zealand, South Korea and Taiwan. At the end of the project there is a brief review of the present industrial policy in Croatia. The research indicated the following conclusions as policy recommendations for Croatia:

* All the countries under consideration have conducted industrial policies over a long period of time so it seems that an industrial policy is a unavoidable building block of every market economy;

* Industrial policy has undergone a transformation from a targeted policy to one relying on horizontal measures;

* Targeted industrial policies are aimed at directly supporting selected industrial sectors (either "national champions" or "lame ducks"). Generally this policy has not proved successful. The state administration has not shown itself to be capable of successfully choosing and effectively supporting chosen sectors;

* An increasing number of economists agree that industrial policy should rely on horizontal policies, i.e. those aimed at supporting key inputs (e.g. invest in infrastructure, finance labour re-qualification schemes, develop information networks for financial markets, support research and development, support environmental protection, etc.). Such interventions benefit all market agents and lead to least relative price distortions;

* Even horizontal state intervention must be limited in time, must consider all costs and benefits, must be as transparent as possible and must distort relative prices as little as possible. 


\title{
STATE INTERVENTION FOR GROWTH PROMOTION IN MARKET ECONOMIES
}

\author{
"It is in fact easy to offer a justification for industrial policy... \\ The difficult questions are how to implement such a policy in practice, and how to \\ manage the political economy of such a policy in such a way to avoid the usual \\ mistakes."
}

Paul Krugman

\section{INTRODUCTION}

The project sought to analyze how developed market economies used state intervention to achieve, increase and facilitate economic restructuring. Since state interventionism covers a wide scope of economic activities performed by the state, for the purpose of this project the scope of state intervention was narrowed. It includes the study of industrial policies, i.e. the policies for sectoral resource allocation management aimed at the achievement of high growth and employment rates. Some economies were more successful in this than others. Drawing both from recent research results and individual country experience, the project attempted to define the necessary ingredients for a successful industrial policy.

As the summary of the research project this paper has two parts. The first provides a survey of the theoretical underpinning of industrial policies. This section deals with the historical development of industrial policy and the policy recommendations for Croatia. The second part surveys the industrial policy experience of Austria, Chile, European Union, Germany, Japan, New Zealand, South Korea and Taiwan with a brief survey of industrial policies currently being implemented in Croatia.

\section{SUMMARY OF RESEARCH RESULTS}

\section{Which industrial policy is the best?}

Many economists have tried to answer this question. Most agree that reasons for industrial policy can be found in market failures (positive and negative externalities, economies of scale, asymmetric information). Even many liberal minded economists 
agree that market failures provide sufficient cause for adopting an industrial policy which will remedy failures and lead the economy to a higher efficiency level. Extensive state intervention and industrial policies are a feature of the period from the Second World War onwards. At the same time there have been ongoing discussions in the professions regarding the most appropriate form of industrial policy. The two opposing camps were the "structuralist" and "liberal". $\underline{\text { Structuralists }}$ argued in favour of a targeted industrial policy and the consequent need to pick and choose which sectors and/or industries to support and then design redistribution of scarce resources along those lines. Liberal economists took the opposite view and were thus more inclined to a hands-off approach and considered industrial policies can only be used when necessary.

In the beginning the philosophy and practice of structuralism dominated together with its policies of picking winners and supporting lame duck industries. Slowly this practice is being abandoned. The current practice of industrial policy is changing as the opinions of structuralists and liberals converge. Thus in the OECD and EU economies it is now generally accepted that an industrial policy should not get involved in the market mechanism, instead it should increase the market's efficiency through horizontal policies. Horizontal policies are those which seek to increase the quality of key production inputs (education, research and development, telecommunications, etc.). Through such measures policy makers in these economies seek to improve the general economic environment and produce effects benefiting all market actors. Such a market oriented industrial policy does not deform the allocation of resources and reduces state intervention to its lowest possible level.

This new approach to industrial policy is a result of economic globalization and the intense international competition it has led to. The business strategy of multinational corporation led to a new phase of development of international economic relations which has been referred to as globalization. This trend has been supported by developments in telecommunications. Its main feature are networks of transnational companies which have organized their activities over a wide area covering more than one national economy. In such circumstances the goals of transnational companies and national governments do not always coincide. The national identity of companies becomes even more blurred when ownership, production and plants are scattered over 
the globe. Products become combinations of components whose source is difficult to determine. In such a business environment funds from targeted industrial policies can easily end up in the pockets of foreign companies instead of intended national champions.

Parallel to the shift towards horizontal policies most economies in the world experienced a reduction of state aid from the relatively high levels of the seventies. For example, in the European Union average state aid in the $1986-88$ period was $2.2 \%$ of GDP, in 1988-90 the average was $2.0 \%$ of GDP and in 1990-92 the average fell to $1.9 \%$ of GDP (Commission of the EC, 1990, 1992, 1995). In all OECD economies during the 1985-88 period aggregate state aid was 2.7\% of GDP but between 1986 and 1989 it fell by $36 \%$, i.e. from 75 mil. to 55 mil USD (OECD, 1992).

\section{Why is targeted industrial policy bad?}

State failure is blamed for many policy errors, this is especially true for industrial policies. For this reason it is necessary to carefully survey state failure and to draw attention to the dangers of excessive state intervention.

It must be remembered that sectors receive economic help through the system of political patronage, i.e. because various policy actors (politicians and civil servants) have personal business interests. Thus when taking decisions they are not neutral and behave in a manner which reflects the preferences and limitations they face. This nonneutrality of public decision making leads to failures called state failures and they are frequently noted as the main reason for failures of industrial policy. The nonneutrality of politicians is due to:

a) Politicians have a short time horizon and are biased towards decisions which give results within their mandate. Since industrial policy is by nature a long term policy, restructuring is frequently postponed or reduced to hastily assembled short term measures.

b) The state's reaction to markets and market changes is slower than the markets themselves, furthermore the state is slow to adapt policies to changing conditions. In addition the state is inert and susceptible to paper pushing where documents are 
passed from one bureaucratic table to another without any action being taken. Controls are difficult to organize because parliament gets relevant facts with a time lag so that it takes its decisions with imperfect information.

c) Narrow interest groups can dominate state intervention and tailor it to there own agenda. Once the state awards a privilege to an interest group it is difficult to take it away. The interest group "captures" the intervention and is not willing to relinquish control. As a result powerful interest groups can divert state intervention towards their personal advancement and away from the public interest.

d) State interventionism can provide an incentives to firms to redirect part of their profits into rent seeking activities, e.g. into lobbying or pay-offs for civil servants. This transforms their hard budget constraint into a soft one. Business results are then not market determined but a result of negotiating terms with the state. The distribution of state aid then becomes a result of the relative strength of participants in the negotiating process. Usually in this process large firms, strategic regions and strong sectors are in a better position to attract aid than small and weak agents.

e) Asymmetric information is crucial in the process of distributing aid and controlling policy implementation. Asymmetric information leads to the principalagent problem. The agent in this case is the firm and potential aid recipient while the state is the principal. The agent has complete information about developments at firm level and can fix his reports and accounts to attract greater aid, e.g. increase his costs above actual ones. The principal is the politician or civil servant who either does not have the necessary information or lacks the motivation to delve deeper into the information provided by the agent. As a result subsidies are usually larger than required and the system has built into it an excess of subsidies.

The effect of state failure is that state intervention leads to a less efficient economy. By deforming relative prices in a way that prices do not reflect scarcities it influences the flow of resources and leads to their less efficient distribution. In 1983 Ramagopal Agarwala showed in a World Bank's study that the greater the price distortions (i.e. the greater their discrepancy from market prices) the greater is the impact on decreasing the rate of growth, the propensity to save and the efficiency of investments (World Bank, 1983) South Korea is one of the few economies which managed to combine a high rate of state intervention with a low level of price distortions and high rates of growth. 


\section{Applied research on industrial policy}

Empirical research should contribute to greater understanding of the costs and benefits of state intervention. Such research is, however rare. This is due to the low transparency of most subsidies while their wide range of economic effects make it difficult to collect all the relevant data required for a comprehensive analysis. In spite of this some research results require reporting.

In Western Germany state aid was almost exclusively awarded to sunset industries. This aid, however, did not lead to their comeback. The most successful sectors (with regard to export potential) were those which did not receive any aid. The failures inherent in helping sunset industries are part of the results derived from research conducted in Australia by the Center for International Economics. The same source concludes that stopping aid to the coal industry (which in 1987 received 10.6 billion DM) would increase German GDP by 38 billion DM while net employment would rise by 157.000 jobs (Commission of the $\mathrm{EC}, 1991)$.

In Japan the MITI's technocrats were not more successful in picking winners (Beason and Weinstein, 1993). The intricate network of aid offered by MITI ended up in slow growth sectors. Like in Germany the Japanese "wise" technocrats chose and aided failing industries. The most recent research results seems to indicate that targeted industrial policy did not contribute to high Japanese growth rates. Long term industrial policy could have, perhaps, even further raised growth rates.

Numerous studies attempt to find a justification for state aid to chosen sectors. Baldwin and Krugman in 1987 studied the costs and benefits of state aid, especially that of Germany and France, to the Airbus project (Ford and Suyker, 1990). State support enabled Airbus to compete with Boeing in the market for wide bodied jets. The economies of scale in producing wide bodied jets is so big that there was a danger that Boeing could end up as their sole producer. Even though this would minimize costs it would also earn Boeing monopoly rents. Under such conditions Airbus's market entry, even with subsidies, possibly transferred part of this rent to Europe thereby increasing Europe's welfare. Since the full extent of subsidies was never made public Baldwin and Krugman's work estimated them at 1.5 billion USD in 1974 dollars. The authors conclude that such a policy was not successful even from the 
European point of view. They calculated that even with a zero discount rate the present value of the Airbus project is negative. America is also a looser because Boeing's loses following Airbus's entry are larger than the benefits of US passengers resulting from fare reductions (which in turn resulted from greater competition and lower prices for planes).

In their 1988 study Soltewedel et al. analyze shipbuilding subsidies in the European Union (Commission of the EC, 1991). These subsidies were very high: France and Italy subsidized up to $50 \%$ of production costs of ships, Denmark, the Netherlands and Great Britain up to $30 \%$ and Belgium and Germany around 20\%. In terms of production and export volume it seems that subsidies had a positive effect in their first year but in the long term there was a negative relationship between subsidies and production levels.

In recent years shipbuilding subsidies have been falling in the European Union. Aid to this sector in 1988-90 equaled $33.8 \%$ of its value added and in 1990-92 fell to $14.6 \%$ of value added. The front runners in the reduction of subsidies are France, Italy, Great Britain and Portugal (Commission of the EC, 1995).

The aid to sunset industries depends on the cause of their decline. The lag can be a result of unfavourable market conditions and thus temporary, or a consequence of loosing comparative advantages and hence permanent. State aid can be justified in the case of temporary lags by the need to provide respite, bridge the slack demand period and maintain production and employment levels during the brief downturn. The strategy can be further defended by the fact that when the cycle picks up further state aid will not be necessary. In real life it is, however, often very difficult to determine whether policy makers are dealing with a short term lag of secular downturn. In most OECD economies a large part of state aid is channeled into sunset sectors (especially shipbuilding and the steel industry) and not into sectors facing short term decline. Such state aid has not been instrumental either in preventing extensive layoffs of workers or in the industry regaining its competitiveness. The opposite seems true. By tying down resources in sectors facing a secular downturn and by artificially maintaining high wages and profits in them the policies hampered required restructuring. In this way many countries (e.g. England and Sweden for textiles, 
France for coal and steel) did not want to admit their lasting loss of comparative advantages in some sectors and embarked on the path of providing large subsidies in the hope that these industries would regain their competitiveness and find a market niche. This approach postponed reallocation of resources into more profitable employment while lay offs were delayed but not prevented. Furthermore, artificially high wages in protected industries made new employment in other sectors more difficult and hence led to even greater unemployment.

Subsidies to sunset industries need not always have such negative results. The Japanese experience points to the importance of timing and determining precisely when a sector or industry starts its decline (Trebilcock, Chandler, Howse, 1990). Thus they quickly and correctly estimated when their textile, shipbuilding and coal industry started its secular downturn and understood that further subsidies would not bring about a reversal. It took other economies a long time (France is the best example) to realize that they were not dealing with a short term temporary phenomena but a secular downturn and act accordingly. Japan is considered the pioneer in the introduction of formalized state aid aimed at subsidizing exit from declining industries. By facing up to market changes the Japanese state decided to use funds to aid firms leaving sunset industries. The purpose of these funds is to reduce the exit costs which would otherwise be borne by the workers and employees. The funds themselves are used for subsidizing a phased exit and worker re-qualification programs. Even though exit subsidies in sunset industries do have disadvantages most authors consider them the most appropriate form of industrial policy for declining industries. Such policies seem to achieve a quick re-allocation of resources along lines dictated by comparative advantages and lead to least efficiency loses.

\section{Croatia and restructuring}

Since the nineties Croatia has been in an economy in transition which has deconstructed its socialist economic system and is building a market economy. After successfully achieving macroeconomic stabilization restructuring remains on the top of the agenda. The central question is how to achieve economic restructuring and what should be the economic role of the state in this process. Restructuring policies and the experience of market economies can make a significant contribution in 
answering these questions. At the same time Croatia has some specific features which must be taken into consideration. They are related both to the transition and to the beak up of former Yugoslavia. The Croatian state faces a number of problems:

a) Extensive resources are blocked in certain sectors. These sectors were chosen according to the economic principles espoused by selfmanaging socialism and are not a result of market driven resource allocation. Were they to be suddenly subjected to market forms these sectors would be in great difficulty. Probably such exposure would result in major excess capacity with sudden and large worker lay-offs. The state must wisely manage the exposure of these sectors to markets so as to minimize the costs of sudden closures.

b) The state is faced with the "stock-flow" problem. On the one hand resources are blocked in sectors which would not "survive" sudden price and foreign trade liberalization while on the other large financial resources are necessary for new investments. With insufficient domestic savings and poor foreign investment it is difficult to create the needed funds in the short term.

c) With a lot of capital still remaining in state ownership ongoing privatization will require the guiding hand of the state. Decisions must be taken regarding the extent of privatization, i.e. which firms to privatize and which to keep in state ownership.

d) States in transition economies have tasks additional to those existing in the West. They must create a complete and consistent legislative system of business laws, they must create market institutions, develop financial information systems and the real estate market, regulate trade, transport and communications, develop an accounting and revision system and transform state owned companies in market oriented ones.

e) The Yugoslav market is lost while that in the former Comecon has partially been lost. At the same time it is difficult to enter new markets. In the meantime productive capacity remains idle, output is falling and unemployment in them rising.

f) After the end of the war and the liberation of most of the country a new aspect of restructuring entered the agenda. The newly liberated areas need to be reconstructed, repopulated and new plants built. In addition there are numerous war damaged plants in areas which were not occupied. The role of the state under such circumstances must be carefully analyzed. 
All the specific features mentioned indicate that state intervention will continue to be necessary in Croatia. The state in transition is facing the challenge of designing the most appropriate model through which to influence markets.

\section{What form should Croatia's industrial policy take?}

It has been reiterated in this report that targeted industrial policy does not lead to the results expected. With the exception of Taiwan and South Korea few countries have achieved favourable results with a targeted industrial policy. During the eighties these policies were largely abandoned (New Zealand in 1984, Chile in 1973-84, Austria in 1986, Germany in the mid 80's) in favour of a different development strategy. On the macroeconomic level this strategy is largely made up of internal economic liberalization connected to opening markets and export expansion, reducing protection levels and increasing the competitiveness of domestic production. Macroeconomic stability with low inflation rates, low unemployment rates and a low fiscal deficit provide additional macroeconomic goals which are not always easy to achieve.

In the light of these experiences industrial policy has shifted from targeted policy measures to horizontal policies supporting key inputs. Following this Croatia should also stress horizontal policy measures in its industrial policy. In that context the following areas are especially important:

a) State investments into infrastructure, especially transport and communications.

b) Training and re-qualification programs for workers leaving industries being shut down. Developing training programs for unemployed young workers and programs for the eradication of long term unemployment. Special attention should be given to developing managerial, marketing and sales skills.

c) Develop new forms of support for research and development activities, incite the diffusion of technological know-how and support the development of international research and science exchange.

d) Create a network of agencies designed to support small and medium sized firms which would disseminate information regarding financial opportunities, new technologies, educational openings, exports, etc. In this way market entry costs are 
reduced and small and medium sized firms can enter activities which they otherwise could not pursue.

e) Design policies influencing new market structures. In this area numerous policies are available: policies designed for small and medium sized firms, control and monitoring of take overs and mergers, anti-monopoly policies, incentives for foreign investments, etc.

f) Further develop environmental protection by internalizing external diseconomies (e.g. by taxing polluters) and regulating pollution emitting industries (e.g. requiring the use of filters).

g) Privatize and reform state owned companies. In the latter case extremely important policies are those aimed at increasing control over management, increasing market exposure and motivating managers for better business results.

h) Approach to loss making industries. International experience has shifted from subsidizing them to subsiding the costs of their market exit. Japan provides a good example in this respect. This approach is especially important because Croatia is facing firm rehabilitation and restructuring.

i) Regional policies do not require any special policy measures. Following the experiences of the European Union the application of the above mentioned policies should provide incentives for endogenous regional development. The policies aimed at the newly liberated areas should also follow this example.

The implementation of these policies depends on some preconditions. These are:

a) Macroeconomic stability which decreases business uncertainty and thereby makes economic accounting possible, both for profits and losses.

b) A competent and independent pro-market oriented state whose interventionism will not distort relative prices too much. A competent administration made up of capable, educated and motivated civil servants supported by a transparent and democratic political system. An independent state implies that it is not under the influence of various interest groups but that it independently and responsibly takes decisions and implements them.

c) Continuous dialogue of all main economic actors can significantly contribute to restructuring. Examples of this are provided by the Austrian experience of Sozialpartnertschaft where government, trade unions and employers cooperate, or the 
New Zealand system of Business Round Table which encompasses executives of the largest industrial firms, other influential social figures and academic economists as well as by MITI's discussions on "visions" in Japan.

d) The development of a stable institutional framework. This must include building of state regulations and legal system which provide a clear and stable framework to the maintenance of financial discipline.

The state has at its disposal various measures for implementing such an industrial policy ranging from subsidies and tax benefits to privatization and deregulation. Each of them has its costs and benefits which must be carefully considered when choosing policies. It is advantageous if state intervention has the following four features:
a) it must be temporary,
b) it must be transparent,
c) it must be aimed at phased reduction of excess capacity and
d) it must distort relative prices as little as possible.

No single instrument satisfies all these positive characteristics. For example tax benefits are much less transparent than direct subsidies or loans. Direct subsidies often lead to an administrative staff which implements them and which can come under the influence of interest groups which make it difficult to control them.

Transparency is an especially important feature of any industrial policy. The state must conduct an industrial policy according to fixed rules and not base it on discretionary decisions. When the state defines clear rules it guarantees transparency, discipline in applying the rules and makes monitoring and control easier. Furthermore in this way the state introduces a climate which enables all participants in the economic game (firms as well as consumers) to perform according to rational economic behavior based on clear expectations concerning the future. 


\section{SUMMARY OF CASE STUDIES}

\section{Austria}

Austrian economic policy generally and industrial policy in particular is under the influence of the tri-partite system (Sozialpartnerschaft). Under this policy arrangement government, trade unions and employees cooperate to maintain economic stability.

Among OECD economies Austria is considered as the economy with the largest public sector and the highest share of nationalized industries. In 1989 32.8\% of all firms were state owned. State firms are managed through a special holding company set up to manage nationalized industry: OEIAG (Oesterische Industries Holding Aktiengesellschaft, founded in 1970). This company is composed of seven holding companies (for mining, machine tool industry, electronics, ferrous metals, non ferrous metals, oil and chemical industry) with 350 firms (EIU,1994).

The Austrian government has been mostly concentrated on one aspect of industrial policy, i.e. policies designed to provide financial support to nationalized industries with the purpose of maintaining high employment.

But the economy started to face major economic problems during the eighties (including an especially high fiscal deficit). This forced the government to reduce financial support and re-examine the role of industrial policy. As a result in 1989 policies designed to provide financial support for nationalized industries were abandoned and replaced by policies aimed at developing new technologies, energy conservation and environmental protection. At the same time subsidies were reduced so that the share of state subsidies fell from $3.2 \%$ of GDP in 1987 to $2.4 \%$ in 1990 (OECD,1990). Presently OEIAG is being reorganized, economic activities are being internationalized (especially links with the EU which are increasing) and many firms are being privatized.

\section{Chile}


Chile abandoned strong state interventionism and embarked on economic liberalization programs. The change started in Chile in 1973 during the period in which General Pinochet's dictatorship was replacing President Allendes socialism.

Under the influence of new neoliberal ideas expounded by the Chicago School and Milton Friedman Chilean economists concluded that the consequences of market failure were more disastrous than those of state failure. As a consequence Chile replaced its import substitution strategy with market allocation of resources and thus was transformed from one of the most protected economies in the world into one of the least protected ones.

Although the change was supported by expensive credits from abroad, inflation was stabilized, exports increased, prices started reflecting scarcities and the Chilean economy became competitive and open to world markets. During the 1977-1981 period GDP growth rates increased to $8 \%$ (Bruno et al. 1991). At the same time real incomes fell, unemployment increased, expensive credits led to high indebtedness and economic inequality increased.

But the Chilean neoliberal experiment which took place during a political dictatorship led to changes due to which a new awareness developed. This is that less state intervention and market allocation of resources was unavoidable for an economy to find its way to the international markets.

\section{European Union}

Industrial policy in the European Union has gone through three phases. The first started when three structural funds were established, i.e. the European Coal and Steel Community (ECSC), the European Regional Development Fund (ERDF) and the European Social Fund (ESF). Their role was to help economic restructuring of EU countries. The second phase started during the eighties. At that time the EU decided to base its growth on endogenous regional growth in different EU regions. This idea was based in the notion that growth must start in the regions themselves and not be managed by a European bureaucracy. Resources from the structural funds are now used for inciting internal, endogenous growth in EU regions. The nineties mark a third stage. The change brought into the limelight the idea that the Union is lagging behind 
US and Japanese development and that industrial policy should be aimed at increasing the competitiveness of the EU's industry.

The problem with EU's industrial policy has always been that it is made up of numerous documents with many agreed goals, recommendations, and priorities of which only a small number have been implemented in practice. The main barrier remains in the strong feeling of national identity among member states and the fear of transferring aspects of national sovereignty to the supranational EU. It is perceived that this would imply the loss of political power and possible dangers for the national economy.

\section{Germany}

Twice in its recent history the German economy was faced with reconstruction with the help of significant external financial assistance. The first time was after the Second World War when the German economy received substantial funds through the Marshall Plan. The second time was when large West German capital injections poured into East Germany during its transition to a market economy.

How were the capital inflows used in each occasion? Post War reconstruction took place in the environment of a social market economy (Soziale Markwirtshaft). In this environment market forces had a greater influence on the economy than public policy. The German principles of a social market economy reflected the approach that structural change should take place under market conditions but that the state would help solve the social problems restructuring creates. In spite of these intentions the state did resort to industrial policy measures such as tax benefits and direct financial transfers which would allocate resources into such sectors as transport, agriculture, housing, shipbuilding, coal production and banking. But during the eighties Germany started abandoning an industrial policy which directly targets chosen sectors in favour of one aimed at both research and development as well as providing incentives for starting new small and medium sized firms. The targeted industrial policy did not prove to be a good policy.

German unification represent a special challenge in which the highly protected East German economy had to be exposed to market criteria. To enable a least painful 
transition East Germany received transfers from West Germany which in 1991 amounted to 50\% of East German 1989 GDP (Federal Office of Trade Information, 1991). Through transfers coupled to investment and tax benefits the federal government's aid to the new regions was funneled into transport, telecommunications, housing construction, environmental protection, education research and development and support for new production programs (i.e. mostly horizontal industrial policy measures). After five years and in spite of many difficulties (especially high unemployment) the economic life in former East German regions has improved and in 1994 it registered a GDP growth rate of $12.4 \%$ (OECD, 1995).

\section{Japan}

Japanese industrial policy is dominated by the Ministry of International Trade and Industry, MITI. The ministry was established after the Second World War.

MITI includes a Commission for Industrial Structure which is made up of representatives of the state, industry, workers, academia and consumer groups. The role of the Commission is to study various questions related to industry and define which new industrial structures are most preferable for the national economy. This "vision" represents a kind of indicative plan and is published and widely distributed with the aim of leading to a social consensus regarding industrial structure. MITI's "vision" is not a formal plan and it does not give specific goals for individual industrial sectors. Instead is outlines priorities (types of products and processes which should be favoured).

In the beginning MITI's role was to control the distribution of loans. Over time MITI transformed and its resources were increasingly used for collecting information, determining economic priorities, promoting the private sector and acting as an intermediary between the domestic and international economy. But MITI also took decisions regarding the distribution of subsidies, direct support to research, soft loans with low interest rates and tax benefits. In addition to helping "sunset industries" eliminate excess capacity at various times is supported different industrial sectors such as: shipbuilding, heavy industry, petrochemicals, research and development in the automobile industry, knowledge intensive industries (computer production), etc. 
But recent research has indicated that MITI's role was not as benign as was thought for many years.

\section{New Zealand}

New Zealand provides a very interesting example of an economy which changed from one of the most highly regulated economies in the world to one of the most liberal ones. The change took place during the eighties, more precisely it started in 1984 when the Labour party came to power and Sir Roger Douglas became the Minister of Finance. He started implementing a completely different policy from the one hitherto known in New Zealand. These economic policies were similar to the ones implemented by the Reagan administration and because of this similarity are referred to as "Rogernomics".

"Rogernomics" describes a strategy of replacing state intervention and a welfare state by free markets and policies in which the ultimate users must pay for the services they enjoy. Furthermore it replaces a highly regulated economy with a highly deregulated economy. As a result export and production subsidies for many products were cut off, soft loans were abolished, reduced tariffs replaced quotas, the state retreated from commercial ventures and there was widespread privatization. While state aid during the seventies averaged $2.3 \%$ of GDP as a result of "Rogernomics" in the eighties it fell to less than $0.6 \%$ of GDP (Ford and Suyker, 1990). This industrial policy was supported by macroeconomic policies. The government was clearly committed to eliminating fiscal and monetary imbalances, i.e. of stopping inflation and reducing the fiscal deficit.

For these policies and reforms the ruling party enjoyed the necessary support in all social classes. Special support came from the Business Round Table. This institution included managers of the largest industrial firms, other notable businessmen and a large number of academic economists.

The results of "Rogernomics" started showing themselves after 1993, i.e. almost a decade after their implementation. Thus in 1994 GDP growth rate reached 6\% (Turkey was the only OECD economy with higher growth rates), inflation rates 
stabilized around $1-2 \%$, the trade deficit was low and the state budget in surplus. In two areas the expected results did not materialize: interest rates remained high (they are not falling below 8\%) and unemployment rates are not decreasing fast enough (they are still 8-9\%) (OECD, 1994).

\section{South Korea}

South Korea offers the best example of an economy which achieved high growth rates and a high level of economic development while relying both on selective state interventionist policies and vigorous markets. In other economies selective industrial policy almost regularly led to low growth rates. In Korea the opposite occurred since Korea managed to achieve high growth rates with strong state interventionism. In the years 1962-1993 Korea achieved one of the highest growth rates in the world since the average yearly growth rate during the period was $8.5 \%(\mathrm{OECD}, 1994)$.

South Korean state intervention was different from the usually used one. Instead of protecting its industry from foreign competition and developing import substitution South Korea used state interventionism for designing strong incentives for export production. As early as 1965 economic policy actors in Korea decided to change their development strategy from import substitution industrialization to a strategy based on strong export development. The whole system of state intervention was aimed at export growth. This policy goal was further supported both by a very flexible political regime which maintained an environment for varied forms of state initiatives and a stable macroeconomic environment.

The success of South Korean state interventionist policies was made possible because these policies were envisaged as a system with a neutral aggregate effect on the economy. As a result in spite of high state interventionism the South Korean economy experienced extremely low levels of price distortions and high aggregate growth rates (World Bank, 1983).

\section{Taiwan}

The Taiwanese experience is frequently referred to as the Far East economic miracle. The Taiwanese economy has been experiencing high growth rates since 1952 together with export expansion, price stability, high employment levels and a relatively 
equitable income distribution. Real GNP in the 1952-1990 period grew at an yearly average of $8.8 \%$ and per capita GNP increased from 100 USD in 1952 to 8000 in 1990 (Kuo, 1994).

What industrial policy led to such impressive results? The choices made by Taiwanese industrial policy did not lead it to chose "wrong industries", indeed it managed to choose some very successful sectors which turned into winners: food processing, textiles, electrical appliances, petrochemicals, metal industry, electronics and machine production.

Many factors led to the Taiwanese success. Some of them are: the inherited infrastructure left by Japanese colonization, the entrepreneurial talent which came from the mainland China, aid from the US (largely as gifts), favourable cycles in the world economy and Confucianism. Even though all these factors played an important role there is another factor which more than the others led to the above average results of the Taiwanese economy. This factor is the state. It was the state which combined all the mentioned factors into a system where each one could make its largest contribution so that they all together lead to the stable accelerated growth.

The Taiwanese state is best described as a strong state operating independently from interest groups. In addition the Taiwanese state has a competent state bureaucracy made up of dedicated and educated civil servants (largely migrants from mainland China). At the same time the state is not in conflict with the market. Indeed the opposite is true since it is a "market friendly" state, i.e. a state which managed to lead and follow market trends. The Taiwanese example shows the extent to which a autonomous and competent state is a prerequisite for implementing an efficient industrial policy which will result in accelerated growth.

\section{Croatia}

The choice of "national winners", i.e. selecting industrial sectors whose development the state systematically supports and whose growth it stimulates, is not a feature of Croatia's industrial policy. The state aid goes mainly to the ailing industries. The influence of the state in the Croatian economy is largely confined to subsidies, transfer payments, financial support from the state budget and tariff protection. Since 
Croatian independence the state budget subsidies and transfers has been used for agriculture as well as for the support of loss making firms, bank rehabilitation, tourism, state railways and shipping companies. The subsidies are disbursed through the relevant ministries.

The main forms of state intervention in agricultural production is the protection of agricultural producers and consumers. The state achieves the former by buying agricultural products and the latter through subsidizing the production of basic agricultural products. The two main forms of state intervention in Croatian agriculture are the price policy and subsidies.

Money from the state budget is also used for restructuring and financial rehabilitation of selected firms. For the selected firms (usually these are the most indebted firms) the support starts by financial rehabilitation, i.e. by applying certain criteria to deal with the firm's debt problem. This is followed by planned financial restructuring and introducing transparent creditor rights towards the firms creditors and banks.

The state directly supported shipbuilding in two ways. The first was by direct loans for building ships and the second was by issuing "big bonds".

The state is also directly involved in bank rehabilitation and restructuring schemes. Instead of giving loans the state has opted for a long term bank rehabilitation and restructuring process. This process will run concurrently with the privatization, restructuring and financial rehabilitation of socially and state owned firms.

State supports the tourist industry through direct cost subsidies. These subsidies cover part of the costs for domestic and foreign tourist transport to some Croatian counties. 


\section{REFERENCES}

\section{Industrial policy (general)}

Adams, Gerard F. and Klein, Lawrence, R. (eds) (1985): "Industrial Policies for Growth and Competitiveness - An Economic Perspective", Lexington Books, Lexington

Auty, Richard M. (1994): "Industrial Policy Reform in Six Large Newly Industrializing Countries: The Resource Curse Thesis", World Development, vol. 22, no. 1

Beason, Richard and Weinstein, David (1993): "Growth, Economies of Scale, and Targeting in Japan (1955-90)", Harvard Institute of Economic Research, Discussion Paper no.1644

Bićanić, Ivo and Škreb, Marko (1992): "A Paradox of Transition to a Market Economy: How Will the Role of the State Change?" in: "Privatization in Europe", editor Targetti, F., Dartmouth, Brookfield, SAD

Boonekamp, Clemens (1989): "Industrial Policies of Industrial Countries", Finance \& Development, no.3

Chenery, Hollis, (ed.) (1979): "Structural Change and Development Policy", Oxford University Press

Commission of the European Communities (1990):"Industrial policy in an Open and Competitive Environment - Guidelines for a Community Approach", Brussels

Commission of the European Communities (1991): “European Economy”, no. 48

Commission of the European Communities (1992): "Third Survey on State Aid in the European Community", Bruxelles

Commission des communautes europeennes (1995): "Quatrieme rapport de la Commission sur les aides d'etat dnas le secteur des produits manufactures et certains autres secteurs de l'Union europeenne", Bruxelles

Cowling, Keith and Sugden, Roger (eds.) (1992): "Current Issues in Industrial Economic Strategy", Manchester University Press

Cowling, Keith and Sugden, Roger (eds.) (1994): "Europe's Economic Challenge", Routhedge, London

Cowling, Keith (1994): "Policies and Strategies: The Issue of Organizational Failure", Bologna Workshop on Industrial Strategy and Integration, mimeo

De Bandt, J (1994): "Policy Mix and Industrial Strategy", in: Europe's Economic Challenge, Cowling K. and Sugden R. (eds)

Ford Robert and Suyker Wim (1990): "Industrial Subsidies in the OECD Economies”, OECD Economic Studies no. 15

Geroski, P.A. (1990): "Procurement Policy as a Tool of Industrial Policy", International Review of Applied Economics, vol.4, no. 2

Grossman, G (1990): "Promoting New Industrial Activities: A Survey of Recent Arguments and Evidence", OECD, Economic Studies, no. 14, pp 87-125 
Hogendorn, Jan S. (1987): “Economic Development”, Harper \& Row, New York

Johnson, Chalmers (1986): "Introduction: The Idea of Industrial Policy", Portfolio International Economic Perspectives, vol. 11, no. 3

Kesner Škreb Marina (1995): "Sektroska investicijska politika", Slobodno poduzetništvo, br. 6

Ke-young Chu and Richard Hemming (1991): "Public Expenditure Handbook”, IMF, Washington, D.C.

Krugman, Paul R. (1986): "Targeted Industrial Policies: Theory and Evidence" Portfolio - International Economic Perspectives, vol. 11, no. 3

Musgrave, A. Richard and B. Peggy (1976): "Public Finance in Theory and Practice”, McGraw Hill Kogakusha

OECD (1992): "Industrial Policy in OECD Countries - Annual Review", Paris

Oughton Christine (1995) :"Bottom-Up and Top-Down Approaches to Industrial Strategy: An Overview", Berlin Workshop, 8-9 september 1995.

Roe, Allan (1984): "Industrial Restructuring: Issues and Experience in Selected Devloping Economies", Technical Paper, World Bank, no. 21

Rop, Anton (1986):"Industrijski kriteriji kroz prizmu korištenja investicijskih kriterija $u$ tržišnoj privredi s jakom državnom regulativom - primjer Austrije", Aktualna vrpašanja družbenog planiranja, Bled no. 4

Schulze, Charles L. (1986): "Industrial Policy: A Dissent", Portfolio - International Economic Perspectives, vol. 11, no. 3

Stern, Nicholas (1989): "The Economics of Development: A Survey" The Economic Journal, no. 99, pp. 597-685

Stiglitz, E. Joseph (1988): "Economics of the Public Sector", W.W. Norton \& Company, New York

World Bank (1983): "World Development Report 1983", Oxford University Press

World Bank (1987): "World Development Report 1987", Oxford University Press

World Bank (1991): "World Development Report 1991", Oxford University Press

Trebilcock, Michael J., Chandler, Marsha A., Howse, Robert (1990): “Trade and Transition: A Comparative Analysis of Adujstment Policies", Routledge, London and New York

Urban, Peter (1986): "Theoretical Justification for Industrial Policy", Portfolio International Economic Perspectives, vol. 11, no. 3

Wolf, Charles, Jr. (1993): "Markets or Governments: Choosing between Imperfect Alternatives" 2nd ed, MIT Press 


\section{Austria}

Aiginger, K., Bayer, K. (1982): "Die Top-Aktion: Eine neue Form der Investitionsfoerderung", WIFO Monats-berichte, vol. 55, no. 10.

Aiginger, K., Clement, W. (1993): "Grundzuege einer Neuen Industriepolitik (Zusammenfassung)", Wien, WIFO/IWI.

Ford, R., Suyker, W. (1990): "Industrial Subsidies in the OECD Economies", OECD Economic Studies, no. 15, Paris

Szopo, P. (1986): "Aspekte der staatlichen Subventionspolitik", WIFO Monatsberichte, vol. 59, no. 9

Szopo, P. (1990): "Direkte Wirtschaftsfoerderung in Oesterreich: Reformimpulse durch Budgetkonsolidierung und EG-Integration", Wien, WIFO

EIU (1994): "EIU Country Profile 1994-95", London

EIU (1994): "The EIU European yearbook 1994-95", London

OECD (1987): "Structural Adjustment and Economic Performance", Paris

OECD (1990): "Modeling the Effects of Agricultural Policies", OECD Economic Studies, no. 13, Special Issue, Paris

OECD (1990): "Reforming Agricultural Policies: Quantitative Restrictions on Production - Direct Income Support", Paris

OECD (1992): "Agricultural Policies, Markets and Trade", Paris

OECD (1993): "Industrial Policy in OECD Countries: Annual Review 1992", Paris

OECD (1993): "The Export Credit Financing System in OECD Member Countries", Paris

OECD Economic Surveys of Austria, different years, Paris

"Foerderungsbericht 1993", Wien, 1994

\section{Chile}

Bosworth, Barry P, Dornbusch, Rudiger and Laban, Raul, (eds) (1994): "The Chilean Economy: Policy Lessons and Challenges", Washington: The Brookings Institutuion

Bruno, Michael ...et al. (eds) (1991): "Lessons of Economic Stabilization and Its Aftermath", Cambridge, Mass. and London: The MIT Press

Cardoso, Eliana and Helwege, Ann (1992): "Latin America s Economy: Diversity, Trends, and Conflicts", Cambridge, Mass. and London, Engl.: The MIT Press

Dornbusch, Rudiger and Edwards, Sebastian (eds) (1991): "The Macroeconomics of Populism in Latin America", Chicago: The University of Chicago Press

Drake, Paul W, (ed) (1994): "Money Doctors, Foreign Debts, and Economic Reforms in Latin America from the 1890s to the Present", Wilmington, Del.: A Scholarly Resources Inc. Imprint 
Gustafson, Lowell S. (ed) (1994): "Economic Development under Democratic Regimes: Neoliberalism in Latin America”, Westport, Conn. and London: Praeger

Gwynne, Robert N. (1991): “Chile to 1994, More Growth under Democracy?", London: The Economist Intelligence Unit, Special Report no. 2065

Hausmann, Richardo and Rigobon, Roberto, (eds) (1993): “Government Spending and Income Distribution in Latin America", Washington: Inter-American Development Bank and The Johns Hopkins University Press

McKinnon, Ronald I. (1988): "Financial Liberalization in Retrospect: Interest Rate Policies in LDCs", in "The State of Development Economics, Progress and Perspectives”, eds. Gustav Ranis and Paul T. Schultz, Oxford: Basil Blackwell

Sachs, Jeffrey (1990): "Social Conflict and Populist Policies in Latin America", San Francisco: ICS Press

Sachs, Jeffrey (1994): "Life in the Economic Emergency Room, u The Political Economy of Policy Reform", ed. John Williamson, Washington: Institute for International Economics

\section{European Union}

Adams , Gerard F. and Klein, Lawrence R, (eds.) (1985): "Industrial Policies for Growth and Competitiveness- An Economic Perspective" Lexington Books, Lexington

Bianchi, Patrizio, (1992a): "The European Community: Industrial Strategy and Structural Policies", in Cowling and Sugden (1992)

Bianchi, Patrizio, (1992b): "Experience in Italy" in Cowling and Sugden (1992)

Bollino, Andrea C. (1985): "Industrial Policy: A Review of European Approaches", in Adams and Klein, 1985

Cowling, Keith and Sugden Roger (eds.) (1992): "Current Issues in Industrial Economic Strategy", Manchester University Press

Commission of the European Communities (1990):"Industrial policy in an Open and Competitive Environment - Guidelines for a Community Approach", Brussels

Commission of the European Communities (1992): "Third Survey on State Aid in the European Community", Bruxelles

Commission des communautes europeennes (1995): "Quatrieme rapport de la Commission sur les aides d'etat dnas le secteur des produits manufactures et certains autres secteurs de l'Union europeenne", Bruxelles

European Commission (1995): “European Economy”, no. 59

IRMO (1994): "Europska unija - Gospodarsko i političko okruženje Hrvatske", Zagreb

European Parliament (1994): "Fact Sheets on the European Parliament and the Activities of the European Union", Luxemburg 
EUROSTAT (1992): "Europe in Figures", Luxemburg

OECD (1992): "Industrial Policy in OECD Countries", OECD, Paris

Ruggiero, R (1978) :"Strumenti Finanziari della Comunita' per le Ristrutturazione e Riconversione Industriale", Atti del Convego AREL, 8-9. May

Samarđija, Višnja (1994): "Europska unija i Hrvatska - Putevi povezivanja $i$ suradnje", IRMO, Zagreb

Stofaes, C. (1978): "La Grande Menace Industrielle", Calman-Levy, Paris

World Bank (1995) : "The World Bank Atlas 1995.", Washington

\section{Germany}

Bundesstele für aussenhandelsinformation (1994): "Wirtschafts-partner Deutschland", Berlin

Dubravčić, Dinko (1991): "Ujedinjenje Njemačke - pouke za tranzicijsku politiku", Ekonomski pregled, broj 10-11-12, str. 483-498

Federal Ministry of Economics (1992): "Investing in the Future, Germany's New Federal States ", Bonn

Federal office of foreign trade information (1991): "Doing Business in Germany's New Federal States", Cologne

Ford, Robert - Sujker, Wim (1990): "Industrial Subsidies in the OECD Economies", u: OECD Economic Studies, no. 15, Autumn 1990, pp. 37-82

Jüttemeier, Karl H. (1987): "Subsidizing the Federal German Economy - Figures and Facts, 1973-1984" Kiel Working Paper no. 279, Institut für Weltwirtschaft, Kiel

Kloten, Norbert (1989): "Role of the Public Sector in the Social Market Economy" in: German Neo-Liberals and Social Market Economy, ed. Peacock A. \& Willgerodt H., St. Martin's Press, New York

OECD (1995): "OECD Economic Outlook", no. 57, Paris

OECD (1983): "Transparency for Positive Adjustment, Identifying and Evaluating Government Intervention", Paris

OECD (1990): "Progress in Structural Reform", Supplement to OECD Economic Outlook no. 47, Paris

OECD (1992): "Industrial Policy in OECD Countries", Annual Review 1992, Paris

Owen-Smith, Eric (1979): "Government intervention in the economy of the Federal Republic of Germany" in: Government intervention in the Developed Economy, ed. Peter Maunder, Croom Helm, London

Tomman, Horst (1992): "Germany", in: "Current issues in industrial economic strategy", Keith Cowling and Roger Sugden (eds), Manchester University Press, Manchester, New York, pp. 184-187 
Vitols, Sigurt (1995): "The German Industrial Strategy: an Overview", Wissenschaftszentrum Berlin, Berlin

Wagenhals, Gerhard (1985): "Industrial Policy in the Federal Republic of Germany: A Survey" in F. Gerhard Adams and Lawrence R. Klein (eds) "Industrial Policy for Growth and Competitiveness", Lexington Books: Lexington

\section{Japan}

Adams, F.Gerard and Ichimura, Shinichi (1983): "Industrial Policy in Japan". in Adams, F.Gerard and Klein, Lawrence Robert (eds.): "Industrial Policy for Growth and Competitiveness". Lexington Books: Lexington

Alam, M.Shahid (1990): "Governments and Markets in Economic Development Strategies: Lessons from Korea, Taiwan, and Japan”. New York, Westport, London: Praeger

Allen, G.C. (1979): "Government Intervention in the Economy of Japan". in: Mawnder, Peter: "Government Intervention in the Developed Economy", London: Croom Helm

Fujita, Masahisa and Tabuchi, Takatoshi (1992): "Regional Growth in Postwar Japan". Paper presented at the 32. RSA European Congress, Brussels, 25-28 August

Hamada, Koichi and Honda, Tetsushi (1995): "Engine of the Rising Sun: Productivity Growth in Postwar Japan". Yale University Economic Growth Center, Center Paper no. 495

Jaklič, Marko (1993): "Framework for the Supply-Side Economic Decision-Making in Slovenia”. Ph.D thesis, Univerza v Ljubljani Ekonomska Fakulteta, Ljubljana

Ichimura, Shinichi (1993): "The Role of Japan in Asia". Occasional Papers no. 36, International Center for Economic Growth

Johnson, Chalmers, Tyson, Laura D'Andrea and Zysman, John (eds.) (1989): "Politics and Productivity: How Japan's Development Strategy Works". Cambridge, Massachusetts: Ballinger Publishing Company

OECD (1990): Economic Studies, Paris

OECD Economic Surveys Japan, Paris, different years

OECD (1983): "Transparency for Positive Adjustment: Identifying and Evaluating Government Intervention”, Paris

Matsumoto, Gentaro (1992): "The Work of the Ministry of International Trade and Industry". in: Cowling, Keith and Sugden, Roger (eds.): Current Issues in Industrial Economic Strategy. Manchester and New York: Manchester University Press

Noland, Marcus (1992): "Indicative Planning in Japan: Discussion". Journal of Comparative Economics, vol. 14, pp. 648-656.

Sato, Kazuo (1990): "Indicative Planning in Japan". Journal of Comparative Economics, vol. 14, pp. 625-647. 


\section{New Zealand}

Blandy, R. and M. Baker (1987): "Industry Assistance Reform and the Labour Market: The New Zealand Experience" Adelaide, National Institute of Labour Studies

Bollard, A. (1992): "New Zealand: Economic Reforms, 1984-1991" San Francisco, ICS Press

Bollard, A. (1984): "Hands on, hands off, or hands-outs: Industry policy for New Zealand" NZ Institute of Economic Research Discussion Paper 28.

Bollard, A. and R. Buckle (eds) (1987): "Economic Liberalisation in New Zealand" Sidney, Allen\&Unwin

Duncan, I., R. Lattimore and A. Bollard (1992): "Dismantling the Barriers, Tariff policy in New Zealand" Research Monograph 57, NZ Institute of Economic Research, Wellington

Enderwick, P. (1993): "Industrial policy in New Zealand: A review of the issues" report prepared for the New Zealand Engineering Union and the New Zealand printing and Related Trades Union

Ford, R. and W. Suyker (1990): "Industrial subsidies in the OECD Economies" OECD Economic Studies no. 15, pp. 37-81

Gillman, M. (1993): "Learning-by-doing growth theory: turning New Zealand's mire into a miracle" Economics Discussion Papers no. 9314, University of Otago, Dunedin

Holmes, F. (ed) (1987): "Economic Adjustment: Policies and Problems" Washington, D.C., International Monetary Fund

Lattimore, R. (1987): "Economic adjustment in New Zealand: A developed country case study of policies and problems" in F. Holmes (ed), pp. 34-84.

OECD (1994): "New Zealand" OECD Economic Surveys Paris

OECD (1993): "New Zealand" OECD Economic Surveys Paris

OECD (1991): "New Zealand" OECD Economic Surveys Paris

OECD (1987): "New Zealand" OECD Economic Surveys Paris

Scollay, R, S. StJohn and J. Horsman (1993): "Macroeconomics: Principles and New Zealand Policy Issues" Auckland, Longman Paul

Urban, P. (1985): "Recent Approaches to Industrial Policy in Australia" in Adams G. and Klein L. (eds)"Industrial Policies for Growth and Competitivness", Lexington Books. Lexington, pp. 189-203.

Wooding, P. (1987): "Liberalizing the international trade regime" in Economic Liberalization in New Zealand edited by A. Bollard and R. Buckle, Wellington Allen \& Unwin 


\section{South Korea}

Amsden, Alice H., and Euh, Yoon-Dae (1993): "South Korea' 1980s Financial Reforms: Good-bye Financial Repression (Maybe); Hello New Institutional Restraints". World Development. vol. 21, no. 3, pp. 379-390

Balassa, Bela (1971): "Industrial Policies in Taiwan and Korea". Weltwirtschaftliches Archiv, Review of World Economics55- 77. vol. 106, no. 1, pp.

Chang, Ha-Joon (1993): "The Political Economy of Industrial Policy in Korea". Cambridge Journal of Economics. vol. 17, pp. 131-157

Chang, Ha-Joon (1995): "Explaining "Flexible Rigidities" in East Asia". in: Killick, Tony: The Flexible Economy: Causes and Consequences of the Adaptability of National Economies. London and New York: Routledge

Cho, Yoon Je (1988): "The Effect of Financial Liberalization on the Efficiency of Credit Allocation". Journal of Development Economics. vol. 29, pp. 101-110

Fujita, Natsuki, and James, William, E. (1989): "Export Promotion and the "Heavy Industrialization" of Korea, 1973-83". The Developing Economies. vol. 27, no. 3, pp. 236-250

Hasan, Parvez and Rao, D.C. (1979): "Korea Policy Issues for Long-Term Development". Baltimore and London: World Bank and The Johns Hopkins University Press

Iqbal, Farrukh (1988): "External Financing for Korea: The Next Phase". World Development. vol. 16, no. 1, pp. 137-155

Jacobsson, Steffan (1993): "The Length of the Infant Industry Period: Evidence from the Engineering Industry in South Korea". World Development. vol. 21, no. 3, pp. 407-419

Jung, Woo S., and Lee, Gyu (1986): "The Effectiveness of Export Promotion Policies: The Case of Korea". Weltwirtschaftliches Archiv, Review of World Economics. vol. 122, no. 2 , pp. $340-358$

Kuznets, Paul (1990): "Indicative Planning in Korea". Journal of Comparative Economics. vol. 14, pp. 657-676

Lee, Keun (1993): "New East Asian Economic Development: Interacting Capitalism and Socialism" New York and London: M.E.Sharpe

Lee, Young Sun (1986): "Changing Export Patterns in Korea, Taiwan and Japan". Weltwirtschaftliches Archiv, Review of World Economics. vol. 122, no. 1, pp. 150- 163 
Leipziger, Danny M. (1988): "Industrial Restructuring in Korea". World Development. vol. 16 , no. 1 , pp. $121-135$

Leite, Sergio Pereira, and Vaez-Zadeh, Reza (1986): "Credit Allocation and Investment Decisions: The Case of the Manufacturing Sector in Korea". World Development. vol. 14 , no. 1 , pp. $115-126$

Naya, Seiji, Urrutis, Miguel, Mark, Shelley, and Fuentes, Alfredo (1989): "Lessons in Development: A Comparative Study of Asia and Latin America". San Francisco: International Center for Economic Growth and Institute for Contemporary Studies

OECD (1993): “Agricultural Policies, Markets and Trade, Monitoring and Outlook 1992”. Paris

OECD (1994): “Economic Surveys 1993-1994 Korea” Paris

OECD (1993): “Industrial Policy in OECD Countries Annual Review 1992”. Paris

\section{Taiwan}

Cheng, T. (1993): "Taiwan in Democratic Transition" in Driven by Growth edited by James W. Morley (New York: ME Sharpe), pp. 193- 218

Kuo, S.W.Y. (1994): "Key Factors for High Growth with Equity - The Taiwan Experience" in: Economic Development of ROC and the Pacific Rim in the 1990s and Beyond edited by Klein, L.R. and Yu, C. (Singapore: World Scientific), pp. 1-18

Lee, K. (1993): "New East Asian Economic Development" (New York: ME Sharpe)

Leipziger, D.M. and Thomas, V. (1993): "The Lessons of East Asia: An Overview of Country Experience" (Washington, D.C.: The World Bank)

Pang, C. (1992): "The State and Economic Transformation" (New York: Garland Publishing, Inc.)

Ranis, G. (1992): "Taiwan - From Developing to Mature Economy" (Boulder: Westview Press)

The Central Bank of China (1995): "Financial Statistics - Taiwan District The Republic of China" (March)

The Central Bank of China (1995): "Balance of Payments - Taiwan District The Republic of China" (March)

Wade, R. (1990): "Governing the Market: Economic Theory and the Role of Government in East Asian Industrialization" (Princeton: Princeton University Press)

Wade, R. (1989): "How to Protect Exports from Protection: Taiwan's Duty Drawback Scheme" - mimeo, Trade Policy Division, The World Bank

\section{Croatia}


Grupa autora (1995): "Studija o pristupnim osnovama za prijem Republike Hrvatske u Svjetsku trgovinsku organizaciju - WTO", Ekonomski institut-Zagreb, Zagreb, February 1995.

Tanić, Stjepan (1994): "Agricultural Sector Review: Agricultural Credit", Ministarstvo poljoprivrede i šumarstva $\mathrm{RH}$

Trlin, Vladimir (1994): "Zaštitna politika Hrvatske $i$ restrukturiranje njenog gospodarstva", u: Konkurentnost Hrvatske, Zagreb: Ekonomski institut-Zagreb

..., "Pregled stanja i strategija razvoja poljoprivrede Republike Hrvatske", Ministarstvo poljopirvrede i šumarstva RH i FAO, studeni 1994.

..., "Pregled potrebnih sredstava za novčane poticaje i naknade za 1995. godinu", Ministarstvo poljoprivrede i šumarstva RH, studeni 1994.

..., "Program financijskog restrukturiranja", Ministarstvo gospodarstva RH, travanj 1995.

..., "Program restrukturiranja hrvatske brodograđevne industrije", Ministarstvo gospodarstva, Sektor brodogradnje, svibanj 1995.

Narodne novine, different years 